\title{
PERENCANAAN PENGUKURAN KERJA DALAM MENENTUKAN WAKTU STANDAR DENGAN METODE TIME STUDY GUNA MENINGKATKAN PRODUKTIVITAS KERJA PADA DIVISI POMPA MINYAK PT BUKAKA TEKNIK UTAMA TBK.
}

\author{
Tutus Rully \\ Dosen Tetap Fakultas Ekonomi Universitas Pakuan \\ Lecturer of Economic Faculty at Pakuan University \\ Noni Tri Rahmawati \\ Mahasiswa Fakultas Ekonomi Universitas Pakuan \\ Student of Economic Faculty at Pakuan University
}

\begin{abstract}
ABSTRAK
Tujuan penelitian ini adalah untuk mengetahui pengukuran kinerja para pekerja, untuk mengetahui produktivitas kerja para pekerja, dan untuk mengetahui pengukuran kinerja dalam meningkatkan produktivitas para pekerja. Metode penelitian yang digunakan adalah metode studi kasus dan menggunakan salah satu metode pengukuran kinerja yaitu metode time study. Hasil dan pembahasan penelitian yaitu terjadi ketidaksesuaian antara teori dengan fenomena yang terjadi di perusahaan, yaitu ada beberapa pekerja yang menggunakan waktu menganggur dan waktu pribadi lebih dari $20 \%$ dari total waktu kerja. Pengawasan yang kurang baik pada kedisiplinan waktu kerja dan waktu standar sangat berpengaruh terhadap tingkat produktivitas kerja para pekerja. Dengan penggunaan waktu standar yang baik, produktivitas kerja meningkat yang ditunjukkan dengan jumlah unit yang semula menghasilkan 2500 perbulan pada setiap produk. Produk Roller Step dibagian pemotongan/cutting meningkat jumlah produknya sebesar 83 unit, dan dibagian finishing meningkat sebesar 1.609 unit. Produk Roller Chain dibagian pemotongan/cutting meningkat jumlah produknya sebesar 53 unit, dan dibagian finishing meningkat sebesar 1.219 unit. Produk Roda Fork Lift dibagian pemotongan/cutting meningkat jumlah produknya sebesar 63, dan dibagian finishing meningkat sebesar 532 unit.
\end{abstract}

Kata Kunci $=$ Pengukuran kinerja, waktu standar dan produktivitas kerja

\begin{abstract}
The purpose of this study was to determine the workers planning work measurement, to determine the productivity of the workers, and to determine the measurement of work in improving the productivity of workers. The method used is a case study and one of measurement method used is a work time study. Results and discussion of this research is a discrepancy between theory and phenomena that occur in the company, that there are some workers who use idle time and personal time more than 20\% (96 minutes) of total working time. Lack supervision on the discipline of working time and standard time greatly affect the productivity levels of workers. With the use of a good standard time, labor productivity increased as indicated by the number of units produced of two workers from 11 units to 14 units.
\end{abstract}

Keyword: Measurement of work, time standards and work productivity standards 


\section{Pendahuluan}

Pada dewasa ini, kegiatan produksi dan operasi merupakan unsur penting dalam sebuah perusahaan. Kelangsungan hidup suatu perusahaan dipengaruhi oleh dari kegiatan produksi dan operasi perusahaan. Kegiatan produksi dan operasi merupakan kegiatan menciptakan barang dan jasa yang ditawarkan oleh setiap perusahaan kepada konsumen. Persaingan di dunia industri nasional yang demikian pesat, khususnya yang bergerak di bidang manufaktur, menyebabkan persaingan usaha semakin meningkat.

Setiap perusahaan sangat membutuhkan tindakan dalam pengukuran tenaga kerja dan pengukuran waktu. Pengukuran tenaga kerja ini dilakukan terhadap segala aktivitas produksi yang ada pada setiap perusahaan. Hasil dari pengukuran tersebut kemudian digunakan dalam memberikan informasi tentang prestasi pelaksanaan suatu rencana kerja dimana perusahaan memerlukan penyesuaianpenyesuaian atas aktivitas perencanaan dan pengendalian dari setiap produksi.

Pengukuran kerja dapat dilihat dari kegiatan proses produksi dan operasi dalam perusahaan apakah efisien atau tidak, yang didasarkan atas lama waktu untuk membuat suatu produk atau melaksanakan pelayanan (jasa). Jumlah waktu yang harus digunakan untuk melaksanakan kegiatan tertentu dibawah kondisi kerja normal disebut standar pekerja (labor standards). Standar kerja yang ditetapkan secara benar, mewakili waktu yang dihabiskan oleh seorang pekerja rata-rata untuk melaksanakan aktivitas tertentu di bawah kondisi kerja normal. Selain itu harus memperhatikan standar waktu yang dibutuhkan oleh para tenaga kerja agar para karyawan dapat menyelesaikan pekerjaannya, berapa lama karyawan dapat menyelesaikan pekerjaannya. Sehingga semakin efektif dan efektif karyawan dalam melakukan pekerjaannya, maka semakin produktif dan nilai yang ditambahkan pada barang yang dihasilkan menjadi lebih tinggi.

Suatu perusahaan biasanya menginginkan waktu kerja yang sangat singkat dalam memenuhi target produksi agar dapat meraih keuntungan yang sebesar-besarnya. Adapun metode yang paling banyak digunakan oleh suatu perusahaan dalam pengukuran waktu adalah studi waktu (time study). Sehubungan dengan hal tersebut, dalam upaya meningkatkan produktivitas kerja dalam setiap kegiatan produksi maka diperlukan pengukuran kerja yang baik. Hal yang perlu dipertimbangkan dalam menentukan pengukuran kerja adalah menentukan waktu standar. Seperti halnya PT Bukaka Teknik Utama Tbk., sistem pengukuran kerja yang ada pada perusahan tersebut tidak berjalan dengan baik. Karena mereka bekerja hanya mengandalkan pengalaman saja tanpa adanya penetapan waktu standar dari perusahaan. Dan juga kurangnya pengawasan waktu kerja bagi para pekerja. Hal ini bisa sangat berpengaruh terhadap tingkat produktivitas kerja pekerja yang masih belum memenuhi target waktu dalam proses memenuhi permintaan konsumen.

Oleh karena itu, tujuan penelitian ini adalah sebagai berikut: 1) Untuk mengetahui pengukuran kerja yang dilaksanakan oleh pada PT Bukaka Teknik Utama,Tbk; 2) Untuk mengetahui tingkat produktivitas kerja karyawan pada PT Bukaka Teknik Utama,Tbk; 3) Untuk mengetahui penerapan pengukuran kerja dalam menentukan waktu standar guna meningkatkan produktivitas kerja pada PT Bukaka Teknik Utama, Tbk.

\section{Metode Penelitian}

Metode analisis data digunakan sebagai tahap lebih lanjut dalam 
menganalisis dari data yang sudah ada. Metode yang digunakan dalam penelitian ini adalah metode Studi waktu ( Time Study).

Adapun langkah- langkahnya adalah sebagai berikut :

1. Identifikasi Elemen

Dalam melakukan penerapan metode studi waktu (Time Study) pada PT Bukaka Teknik Utama Tbk., pekerjaan dibagi ke dalam beberapa elemen kerja.

2. Menentukan Jumlah Siklus

Hitung waktu siklus rata-rata $(\bar{X})$ dengan rumus :

Di mana :

$$
\bar{X}=\frac{\sum X i}{n}
$$

$\bar{X} \quad=$ siklus rata-rata

$\sum X i=$ Jumlah waktu siklus

$n=$ sampel kerja karyawan

3. Tetapkan Peringkat Kinerja

Langkah berikutnya dari metode studi waktu adalah tentukan waktu normal untuk setiap elemen kerja yang dilakukan oleh karyawan berdasarkan observasi. Waktu normal dapat dihitung dengan rumus sebagai berikut :

$$
N T=\bar{X} \times \frac{P R}{100}
$$

Dalam hal ini :

NT = waktu normal

$\mathrm{PR}=$ Peringkat Kinerja (dalam persen)

Peringkat kinerja diperlukan untuk penyesuaian waktu yang diperoleh dari pengamatan terhadap satu orang pekerja menjadi waktu normal berlaku bagi seluruh pekerja.

4. Tetapkan Faktor Kelonggaran (allowance factor)
Faktor

kelonggaran diperlukan untuk mencakup interupsi/penundaan yang terjadi karena keperluan pribadi pekerja (untuk minum, ke kamar kecil, atau istirahat) dan penundaan yang tidak bisa dihindari (seperti mesin/peralatan rusak, material terlambat, atau gangguan listrik). Faktor kelonggaran dihitung sabagai proporsi dari waktu kerja yang hilang karena penundaan tersebut, yang dinyatakan dalam persen.

5. Hitung Waktu Standar

Untuk mendapatkan standar waktu (standar Time atau ST), maka besarnya waktu normal harus disesuaikan dengan allowance factor (AF) yang besarnya antara $10 \%$ hingga $20 \%$ dari waktu normal. Waktu standar dapat dihitung dengan rumus :

$$
\mathrm{ST}=\frac{\mathrm{NT}}{1-\mathrm{AF}}
$$

Dalam hal ini :

$$
\begin{array}{llr}
\mathrm{ST} & =\text { waktu standar } & \\
\mathrm{NT} & =\text { normal time } & \\
\mathrm{AF} & =\text { proporsi waktu normal } \\
\text { yang } & \text { ditambahkan } & \text { untuk } \\
\text { allowance factor } &
\end{array}
$$

6. Menghitung Produktivitas Kerja

Dari setiap masing-masing elemen kerja yang ada, dengan cara membandingkan antara output (barang jadi yang dihasilkan) dibagi dengan input (tenaga kerja) Pengukuran produktivitas dapat menggunakan rumus :

$$
\text { Produktivitas }=\frac{\text { ouput }}{\text { input }}
$$

Di mana:

Output $=$ barang yang dihasilkan Input $=$ jam kerja 


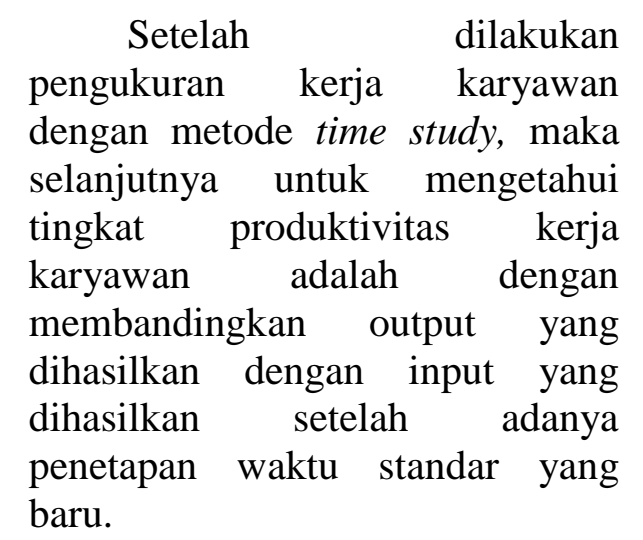

III. Hasil dan Pembahasan

PT Bukaka Teknik Utama Tbk merupakan perusahaan yang bergerak dibidang Rancang - Bangun Rekayasa, Konstruksi dan Manufaktur (Bidang Energi, Transportasi dan Telekomunikasi).Dari tahun ke tahun perusahaan mampu meningkatkan kualitasnya. Hal ini Di buktikan dengan perolehan sertifikak ISO 9001. Pada tahun 1995, perusahaan Mendapatkan sertifikat American Petroleum Institute untuk kegiatan bidang minyak Dan gas bumi.

\subsection{Pengukuran kerja karyawan pada divisi pompa minyak PT Bukaka Teknik Utama Tbk.}

Dalam divisi pompa minyak PT Bukaka Teknik Utama Tbk., proses pengukuran kerja yang dilakukan oleh pimpinan perusahaan berjalan cukup baik dan pimpinan perusahaan telah berhasil membentuk suatu kerjasama antar pekerja yang satu dengan pekerja yang lainnya.

Namun, setelah penulis melakukan observasi secara langsung dan melakukan wawancara kepada beberapa pekerja, penulis menemukan beberapa kekurangan dari tingkat kinerja karyawan tersebut dan penulis menemukan suatu ketidaksesuaian antara teori dengan fenomena yang terjadi pada proses pembuatan samson post. Berikut fenomena yang ada :

1) Waktu dasar bekerja yang di tentukan perusahaan adalah sebesar 8 jam.

2) Dalam proses pengukuran kerja, perusahaan memberikan kebijakan waktu menganggur dan waktu pribadi sebesar 20\% (96 menit) dari total waktu kerja, ini mencakup kegiatan di luar proses produksi, seperti makan siang, minum, ke toilet, dan sebagainya. Namun ada beberapa pekerja yang menggunakan waktu menganggur dan waktu pribadi lebih dari $20 \%$ dari total waktu kerja.

3) Dalam proses produksi, perusahaan tidak memberlakukan pengawasan yang ketat terhadap waktu kerja karyawan dan tidak ada waktu standar yang tetap.

4) Waktu standar yang ditetapkan perusahaan tidak berjalan dengan baik, sehingga banyak waktu yang tidak efektif dan efisien yang berpengaruh terhadap rendahnya tingkat produktivitas kerja karyawan.

Setelah melakukan penerapan pengukuran kerja dengan menggunakan metode time study dan penentuan waktu standar, maka terjadi peningkatan produktivitas kerja pada kedua pekerja tersebut. Berikut ini adalah tabel komparatif dari produktivitas kerja kedua pekerja, sebagai berikut:

Tabel 3.1.

Perbandingan Produktivitas Kerja

Proportionate of Work Productivity 


\begin{tabular}{|c|c|c|}
\hline Keterangan & $\begin{array}{c}\text { Standar Perusahaan } \\
\text { (Menit) }\end{array}$ & $\begin{array}{c}\text { Standar Penulis } \\
\text { (Menit) }\end{array}$ \\
\hline Total waktu Kerja & 960 & 960 \\
\hline Waktu Standar & 140 & 130,87 \\
\hline Unit yang dihasilkan & 6,86 unit & 7,33 unit \\
\hline $\begin{array}{c}\text { Standar Produktivitas } \\
\text { Kerja }\end{array}$ & 0,429 unit/jam & 0,458 unit/jam \\
\hline
\end{tabular}

Setelah mengetahui standar unit yang dihasilkan, maka tingkat produktivitas pekerja pun akan meningkat, sebagaimana data berikut:

Tabel 4.6

Tingkat Produktivitas Kerja

Rate of Work Productivity

\begin{tabular}{|c|c|c|c|}
\hline Pekerja & $\begin{array}{c}\text { Produktivitas } \\
\text { (Pra-Time Study) }\end{array}$ & $\begin{array}{c}\text { Produktivitas } \\
\text { (Pasca Time Study) }\end{array}$ & $\begin{array}{c}\text { Peningkatan } \\
\text { Produktivitas }\end{array}$ \\
\hline Pekerja 1 & 0,25 unit/jam & 0,458 unit/jam & 0,208 unit/jam \\
\hline Pekerja 2 & 0.375 unit/jam & 0,458 unit/jam & 0,083 unit/jam \\
\hline Pekerja 3 & 0,25 unit/jam & 0,458 unit/jam & 0,208 unit/jam \\
\hline Pekerja 4 & 0,375 unit/jam & 0,458 unit/jam & 0,083 unit/jam \\
\hline Pekerja 5 & 0,25 unit/jam & 0,458 unit/jam & 0,208 unit/jam \\
\hline
\end{tabular}

Dari data di atas dapat disimpulkan bahwa tingkat produktivitas kerja pekerja 1 dan pekerja 2 belum maksimal dan dapat tingkatkan melebihi standar produktivitas perusahaan yang ada. Ini bisa dilihat dari jumlah unit yang dihasilkan sebelumnya sebanyak 11 unit menjadi 14 unit.

Faktor yang menyebabkan produktivitas naik adalah karena standar waktu yang ditetapkan lebih cepat dari sebelumnya. Hal ini bisa terjadi karena sedikitnya waktu yang terbuang dalam setiap prosesnya sehingga para pekerja bekerja lebih efisien dan efektif dalam setiap proses produksi.

\section{Kesimpulan}

Kesimpulan penulis dari hasil penelitian ini adalah sebagai berikut :

1. Penulis menemukan adanya ketidaksesuian antara teori dengan fenomena yang ada: 
a. Penetapan waktu standar pada PT Bukaka Teknik Utama Tbk. divisi pompa minyak tidak berjalan dengan baik karena tidak adanya pengawasan yang ketat terhadap waktu kerja para pekerja.

b. Banyak pekerja yang menggunakan waktu menganggur dan waktu pribadi yang melebihi dari yang ditetapkan PT Bukaka Teknik Utama Tbk. divisi pompa belum maksimal karena banyaknya karyawan yang kurang disiplin waktu kerja.

3. Berikut perbandingan waktu standar yang ditetapkan PT Bukaka Teknik Utama Tbk. divisi pompa minyak dengan hasil penelitian penulis dari pengamatan yang dilakukan:

a. Proses cutting dengan waktu standar 30,94 menit, sedangkan waktu yang ditetapkan perusahaan sebesar 35 menit.

b. Proses setting dengan waktu 50,63 menit, sedangkan waktu yang ditetapkan perusahaan sebesar 55 menit.

c. Proses welding dengan waktu 41,86 menit, sedangkan waktu yang ditetapkan perusahaan 45 menit.

d. Proses finishing dengan waktu 7,66 menit, sedangkan waktu yang ditetapkan perusahaan 10 menit.

\section{Daftar Pustaka}

Aquilano and Davis, Chase, 2004, Fundamentals of Operation minyak sebesar 20\% (96 menit) dari total waktu kerja.

c. Banyak waktu standar yang terbuang sehingga berpengaruh terhadap tingkat produktivitas kerja para pekerja.

2. Hasil penelitian tingkat produktivitas dari 5 orang pekerja yang terampil: Berdasarkan dari perhitungan diperoleh bahwa tingkat produktivitas kerja tersebut

Managemen. America: Mc.Grow Hill

Eddy Herjanto, 2008, Manajemen Operasi, Edisi Ketiga,Grasindo.

Hasibuan Malayu. 2005. Manajemen Sumber Daya Manusia. Jakarta: PT. Bumi Aksara.

Heizer Jay and Render Barry, Operations Management, 2006, Alih Bahasa

Dwi Anoegrahawati S, M.Eng.Sc. dan Indra A., Msc., Edisi Ketujuh, Salemba Jakarta.

Herlin Hidayat, 2014, Manajemen Operasi - Dasar, Edisi Pertama. Jakarta: Universitas Atma Jaya

Hery Prasetya dan Fitri Lokiastuti, 2011, Manajemen Operasi, Edisi pertama. Yogyakarta: CAPS.

Irham Fahmi. 2012. Manajemen operasi dan produksi. Bandung: CV Alfabeta.

Kumar, S. Anil and N. Suresh, 2008, Operations Management, second edition. New Delhi: New Age International $(\mathrm{P})$ Limited

Kumar, S. Anil and N. Suresh, 2009, Operations Management. New Delhi: New Age International Publisher

M. Manulang. 2009. Dasar - Dasar Manajemen. Edisi 21. Jakarta: Ghalia Indonesia.

Maria Pampa Kumalaningrum, Heni Kusumawati dan Rahmat 
Purbandono Hardani, 2011, Manajemen Operasi, Edisi Kedua. Yogyakarta: UPP STIM YKPN

R. Pannerselvam. 2006. Production Operation Management. New Delhi.Tata McGraw - Hill

Russell, Roberta S And Bernard W. Taylor. 2011. Operations Managements. John Willey and Sons, inc. United States of America. 